\title{
Trapping-a major tactic of BIPM strategy of palm weevils
}

\author{
S. P. Singh ${ }^{1}$ and P. Rethinam ${ }^{1}$
}

\begin{abstract}
Several species of curculionid weevils such as Amerrhinus ynca Sahlberg, Cholus annulatus Linnaeus, $C$. martiniquensis Marshall, C. zonatus (Swederus), Diocalandra frumenti (Fabricius), Dynamis borassi Fabricius, Homalinotus coriaceus Gyllenhal, Metamasius hemipterus Linnaeus, Paramasius distortus (Gemminger \& Horold), Rhabdoscelus obscurus (Boisduval), Rhinostomus barbirostris (Fabricius), R. afzelii (Gyllenhal), Rhynchophorus bilineatus (Montrouzier), R. cruentatus Fabricius, R. ferrugineus (Olivier), R. palmarum (Linnaeus) and R. phoenicis (Fabricius) are associated with palms. Some of these have become a major constraint in the successful cultivation of coconut palm (Cocos nucifera $\mathrm{L}$.), date palm (Phoenix dactylifera L.) and oil palm (Elaeis guineensis L.). R. ferrugineus is distributed in over 33 countries and attacks more than two dozen palm species. In the recent past, it has spread to Middle Eastern countries, Mediterranean region of Africa and southern Europe (Spain) causing tremendous economic losses. The yield of date palm has decreased from 10 to 0.7 tons/ha. Coconut palms in India are infested upto 6.9 per cent in Kerala and 11.65 per cent in Tamil Nadu. R. palmarum is a major pest of oil and coconut palms in the tropical Americas and, vectors the nematode, Bursaphelenchus cocophilus (Cobb) Baujard which causes red ring disease (RRD). Palm losses due to RRD are commonly between 0.1 to $15 \%$ which amounts to tens of millions dollars. The status of other species is briefed. The grubs of weevils that develop in the stems, bud, rachis of leaves and inflorescence of cultivated, ornamental or wild palms cause direct damage. Because of the cryptic habitat of the grubs, which act as tissue borer, the management becomes difficult.
\end{abstract}

Twenty-nine species of natural enemies are associated with palm weevils. The traditional method of controlling palm weevils included sanitation; pesticides and poisoned traps baited with petioles of coconut, stalks of sugarcane, tissues of pineapple or banana fruits.

Kairomones such as pure ethanol or isoamyl acetate have been found as attractive as or even more attractive than natural plant tissue (pineapple vs. isoamyl acetate). Palm weevils (Rhynchophorus palamrum, $R$. phoenicis, $R$. ferrugineus D. borassi, M. hemipterus, $R$. obscurus, and P. distortus) use male-produced aggregation pheromones for intraspecific chemical communication, (4S, 5S)-4-methyl-5-nonanol (ferrugineol) is the major aggregation pheromone for $R$. ferrugineus, $R$. vulneratus, $R$. bilineatus, $M$. hemipterus, and D. borassi and a minor component for $R$. palmarum, (5S, 4S)-5-methyl-4-octanol (cruentol), (3S, 4S)-3-methyl-4-octanol (phoenicol) and (4S, 2E)-6-methyl-2-hepten-4-ol (rhynchophorol) are the main aggregation pheromones for $R$. cruentatus, $R$. phoenicis, and $R$. palmarum, respectively. Plastic bucket modified into pheromone trap with synthetic pheromone and synergist (sugar cane stalk or palm petiole or banana fruit) immersed with carbofuran, hung on palms stems at about $1.5-1.7 \mathrm{~m}$ above the ground formed a sustained pheromone based trapping system. The sugessions for future management initiatives including areawide trapping, evaluation of trap-palm species and formulation of an international network project are given.

Key words: Palm weevils- Amerrhinus ynca, Cholus annulatus, C. martiniquensis, C. zonatus, Diocalandra frumenti, Dynamis borassi, Homalinotus coriaceus, Metamasius hemipterus, Paramasius distortus, Rhabdoscelus obscurus, Rhinostomus barbirostris, $R$. afzelii, Rhynchophorus bilineatus, $R$. cruentatus, $R$. ferrugineus, $R$. palmarum and $R$. phoenicis; coconut palm, date palm, oil palm, Oncospernus tigillaria, Metroxylon solomenense, trapping, biointensive integrated pest management (BIPM).

\footnotetext{
${ }^{1}$ Asian and Pacific Coconut Community, Jakarta, Indonesia
} 


\section{Introduction}

Several species of weevils are closely associated with Palmae (Kalshoven, 1981). Some of the species of weevils (family Curculionidae of order Coleoptera) have become a major constraint in the successful cultivation of coconut palm (Cocos nucifera Linnaeus), date palm (Phoenix dactylifera Linnaeus) and oil palm (Elaeis guineensis Linnaeus). In the recent past, red palm weevil, Rhynchophorus ferruginus Olivier has spread to Middle Eastern countries, Mediterranean region of Africa and southern Europe (Spain) causing tremendous economic losses and derailing the economy of some of the countries which are mainly dependent on date palm. In infested areas, the yield of date palm has decreased from 10 to 0.7 tons/ha (Gush, 1997). American palm weevil, Rhynchophorus palmarum (Linnaeus) is a major pest of cultivated oil and coconut palms in the tropical Americas (Wattanapongsiri, 1966). Although $R$. palmarum can kill palms through direct attack, its major threat to palm plantations lies in its being the vector of the nematode, Bursaphelenchus (Rhadinaphelenchus) cocophilus (Cobb) Baujard (Cobb, 1922; Tidman, 1951; Hagley, 1963: Martyn, 1953; Griffith, 1967, 1978, 1987) which causes red ring disease (RRD). Palm losses due to RRD are commonly between 0.1 to $15 \%$ (Chinchilla, 1988) which amounts to to tens of millions dollars.

Grubs of weevils bore into the palms and eventually make them unproductive. Because of the cryptic habitat of the grubs, which act as tissue borer, the management becomes difficult. The weevils use odor cues to orient to their host plants. The traditional method of controlling palm weevils has been the use of poisoned traps baited with damage tissue of coconut, sugarcane, pineapple, or banana fruits (Morin et al., 1986). In fact, baiting and trapping of adult weevils using a mixture of materials has been considered as one of the best options for lowering the overall population of weevils in a given area. This paper besides discussing the trapping of adult weevils briefly throws light on other aspects of weevils, which could help in devising a sound management strategy for these naferious pests.

\section{Species composition, biography and behaviour of palm weevils}

The species of palm weevils recorded are presented in Table 1. Ten species of the genus Rhynchophorus are known, of which the greatest part are pests of cultivated palms (Wattanapongsiri, 1966). Rhynchophorus spp. is major pests of coconut, oil palm, date palm and sugarcane (Wattanapongsiri, 1966). Grubs that develop in the stems, bud, rachis of leaves, and inflorescence of cultivated, ornamental, or wild palm trees cause damage (Wattanapongsiri, 1966). They adults cause indirect damage to palm trees by vectoring the nematode Bursaphelenchus cocophilus, which is responsible for red ring disease (Griffith, 1987).

Asiatic palm weevils, Rhynchophorus ferrugineus and $R$. vulneratus (Panzer) are important pests in South Asia. The Southeast Asian Oncospernus tigillaria is a preferred host for breeding of $R$. vulneratus (Wattanapongsiri, 1966). Wattanapongsiri (1966) maintains that $R$. vulneratus is a species distinct from $R$. ferrugineus inspite of the fact that both the species share distribution, life history parameters and host plants (Murphy and Briscoe, 1999) and chemical composition of the pheromones produced (Perez et al., 1995). At best $R$. vulneratus should be considered as colour morph of the same species. Unless other pre- or postzygotic reproductive isolating mechanisms are discovered, the species should be synonymized with Rhynchophorus ferrugineus (Olivier). But the congener $R$. bilineatus differed from them by $10 \%$, suggesting divergence of these lineages about 5 million years ago. Interestingly, this species was originally known as a sub-species of $R$. ferrugineus: Rhynchophorus ferrugineus papuanus Kirsch (Kalshoven, I981). In addition to $R$. vulneratus the taxonomic status of Asian Rhynchophorus species such as $R$. distinctus Wattanpongsiri, $R$. lobatus Ritsema and others is not clear and some may be conspecific with $R$. ferrugineus. 
Table 1. Record of common palm weevils*

\begin{tabular}{|c|c|c|}
\hline Name of the pest & Geographical distribution & Pest status \\
\hline Amerrhinus ynca Sahlberg (=Ameris ynca) & Brazil & Minor / primary \\
\hline Cholus annulatus Linnaeus & $\begin{array}{l}\text { Western hemisphere } \\
\text { (Guyana) }\end{array}$ & Minor / primary \\
\hline Cholus martiniquensis Marshall & $\begin{array}{l}\text { Western Hemisphere } \\
\text { (St. Lucia) }\end{array}$ & Minor / primary \\
\hline Cholus zonatus (Swederus) & Western Hemisphere & Primary \\
\hline $\begin{array}{l}\text { Diocalandra frumenti (Fabricius) } \\
\text { (four-spotted weevil) }\end{array}$ & $\begin{array}{l}\text { Southeast Asia; Oceania; } \\
\text { Africa }\end{array}$ & Minor / primary \\
\hline Dynamis borassi Fabricius & Colombia & Major \\
\hline Homalinotus coriaceus Gyllenhal & Brazil; Argentina & Minor / primary \\
\hline Metamasius hemipterus Linnaeus & $\begin{array}{c}\text { Africa; Western } \\
\text { Hemisphere; Indonesia } \\
\text { (? intercepted) }\end{array}$ & Minor / primary \\
\hline $\begin{array}{l}\text { Paramasius distortus (Gemminger \& Horold) } \\
\text { (=Metamasius inaequalis Gyllenhal) }\end{array}$ & Western Hemisphere & Minor / primary \\
\hline Rhabdoscelus obscurus (Boisduval) & Micronesia and Hawai & Primary \\
\hline $\begin{array}{l}\text { Rhinostomus barbirostris (Fabricius) } \\
\text { (bearded weevil) }\end{array}$ & $\begin{array}{l}\text { South America; West } \\
\text { Indies }\end{array}$ & Primary \\
\hline Rhinostomus afzelii (Gyllenhal) & Africa & Primary \\
\hline $\begin{array}{l}\text { Rhynchophorus bilineatus (Montrouzier) } \\
\text { (black palm weevil) }\end{array}$ & Indonesia; Oceania & Primary \\
\hline Rhynchophorus cruentatus Fabricius & North America & Primary \\
\hline $\begin{array}{l}\text { Rhynchophorus ferrugineus (Olivier) (Asiatic } \\
\text { palm weevil) }\end{array}$ & $\begin{array}{l}\text { South and southeast Asia; } \\
\text { Middle East; Oceania; } \\
\text { Africa; southern Europe }\end{array}$ & Major \\
\hline $\begin{array}{l}\text { Rhynchophorus palmarum (Linnaeus) (South } \\
\text { American palm weevil) }\end{array}$ & Confined to New World & Major \\
\hline $\begin{array}{l}\text { Rhynchophorus phoenicis (Fabricius) } \\
\text { (African palm weevil) }\end{array}$ & Widespread in Africa & Major \\
\hline
\end{tabular}

* Based on Hill (1983) and CABI (2002)

Rhynchophorus ferrugineus may consist of a number of biotype populations each adapted to feeding on a particular group of palm genera. $R$.. ferrugineus specimens collected in India from Arsikere (Karnataka) were different from those collected from Maharashtra and Tamil Nadu showing the biotypic variations. Also variations in the biotic characters (fecundity and sex ratio) of $F_{1}$

and $\mathrm{F}_{2}$, progenies of (Ramachandran, 1998) were observed. Fluctuation in weather is also believed to influence the insect behaviour and morphology.

Rhynchophorus ferrugineus has a wide distribution as a pest of coconut palm in the South Asian region. There are also evidences 
of its distribution in the Mediterranean region of Africa besides its report from southern Europe (Esteban-Duran et al., 1998a, b) where it mainly attacks date palm. Report on $R$. ferrugineus was first published in 1891 in Indian Museum Notes (1891/3); later Lefroy (1906) recorded it as a pest of coconut in India, Green (1906) from Sri Lanka and Banks (1906) from the Philippines. Buxton (1920) reported $R$. ferrugineus from Iraq (Mesopotamia) on date palm. But inspite of its report from Iraq, the pest extended its invasion of date palm gardens of Gulf countries only in last two decades. The pest was first recorded in the northern United Arab Emirates (UAE) in 1985, and since then it has spread to almost the entire UAE (Anonymous, 1995; El Ezaby, 1998), Saudi Arabia and Qatar during 1985, Oman and Kuwait in 1993 (Anonymous, 1995). In Iran, it was recorded in Savaran region in 1990 (Faghih, 1996). It was discovered in Egypt at the end of November 1992 in El-Hussinia, Sharquiya region (Cox, 1993). In 1994, it had been captured in the south of Spain (Barranco et al., 1996) and in 1999 it reached Israel, Jordan and the Palestinian Authority Territories (Kehat, 1999). Currently $R$. ferrugineus is distributed in Bangladesh, Bahrain, Cambodia, China, Egypt, India, Indonesia (Sumatra, Java, Kalimantan, Lombok, Sulawesi, Papua province and many of the smaller islands), Iran, Iraq, Israel, Japan (Nokonoshima island), Jordan, Kuwait, Laos, New Caledonia, Malaysia, Myanmar, Oman, Pakistan, Palestinian Authority Territories, Papua New Guinea, Philippines, Qatar, Samoa, Saudi Arabia, Singapore, Solomon Islands, Spain, Sri Lanka, Taiwan (China), Thailand, United Arab Emirates and Vietnam.

In Egypt, $R$. ferrugineus was introduced through importation of offshoots from the United Arab Emirates and in south of Spain from adult palms imported from Egypt (Egypt has been the main source of supply of ornamental adult Phoenix palms to satisfy the very substantial demand that exists in all the coastal cities of Spain and, more generally of southern Europe). It might have spread to other countries such as Algeria, Morocco and Mediterranean area. Date palm, Phoenix dactylifera and Cannary island date palm, $P$. canariensis are the main crop and ornamental species in the Mediterranean area, but it could also attack some other ornamental palms (Barranco et al., 2000). In infested plantations, yields have been estimated to drop from 10 tonnes to 0.7 tonnes per hectare (Gush, 1997). The cause of the high rate of spread of this pest is human intervention, by transporting infested young or adult date palm trees and offshoots from contaminated to uninfected areas.

The male and female adults of $R$. ferrugineus are large reddish brown beetles, $30-50 \mathrm{~mm}$ in length, generally with longitudinal brightly coloured bands. Adults are very good fliers, can fly up to $1.2 \mathrm{~km}$ uninterrupted (Wattanapongsiri, 1966). The female uses its long curved rostrum (a snoutlike projection of the head) for feeding and to bore into the tissue to form a hole in which to oviposit its light-yellow eggs (2.62 $\mathrm{mm}$ long and $1.12 \mathrm{~mm}$ in width) on the wounds of various origins (pruning or chain saw wounds, lightening damaged or injury caused by rhinoceros beetle or stressed due to any other injury), on spindle, tender leaf, mature stem as well as in the crown, undamaged palms are also attacked (Wattanapongsiri, 1966; Kalshoven, 1981; Murphy and Briscoe,1999). Several eggs are laid together but not in contact, and then the hole is cemented over to protect the eggs. On young, growing date palms, the weevils take shelter under the splitting bark and lay eggs within the newly emerging roots (Abraham et al., 1998). Usually the adults select palms in the nearby vicinity for egg laying probably due to the aggregated spatial distribution of the pest (Faleiro et al., 2002). The males of $R$. ferrugineus produce a pheromone, which causes the weevils to aggregate on damaged trees (Gunawardena and Bandarage, 1995). In general palms of 5-20 years are susceptible. 
Table 2. Biography of Rhynchophorus ferrugineus

\begin{tabular}{|c|c|c|c|c|c|c|}
\hline \multirow{2}{*}{ Stage } & \multicolumn{5}{|c|}{ Duration of development stages in different countries (in days) } \\
\cline { 2 - 7 } & India* & Indonesia* & Myanmar* & Philippines* & Iran* & Spain ** \\
\hline Eggs per female & $127-276$ & 531 & 300 & $62-350$ & $62-350$ & $58-243$ \\
\hline Incubation period & $3-4$ & 3 & $3-4$ & 3 & $1-6$ & - \\
\hline Larval period & $25-61$ & $60-105$ & $30-105$ & $\begin{array}{c}35 \text { male } \\
38 \text { female }\end{array}$ & $41-78$ & $76-102$ \\
\hline $\begin{array}{c}\text { Pupal period } \\
\text { Duration of life } \\
\text { cycle }\end{array}$ & $18-33$ & $3-17$ & $17-50$ & $\begin{array}{c}1-19 \text { male } \\
2-19 \text { female }\end{array}$ & $5-27$ & $19-45$ \\
\hline $\begin{array}{c}\text { Longevity: male } \\
: \text { female }\end{array}$ & $\begin{array}{c}50-90 \\
50-90\end{array}$ & 60 & $60-165$ & $\begin{array}{c}45-68 \text { male } \\
45-67 \text { female }\end{array}$ & $57-111$ & $100-139$ \\
\hline
\end{tabular}

*Adopted from Murphy and Briscoe (1999); **Adopted from Esteban-Duran et al. (1998a).

On an average, females are capable of laying 250 eggs (Murphy and Briscoe, 1999), which hatch in three days. On hatching from the eggs, the whitish-yellow young grubs start feeding on soft palm tissue, by making tunnels in the tree crown, upper part of the trunk and at the base of petioles. They can also bore into the trunk of young palms and the decaying tissue of dying palms; Kalshoven (1981) reports that they can develop in the refuse formed during the processing of sago.

The grubs feed within the host, chew the tissue, work back the chewed fibre and seal the tunnel so that entry of any other organism is prevented. They can be found in any place within the palm, even in the very base of the trunk where the roots emerge. In severely infested palms, cavities are formed by the feeding grubs, which weaken the crown of the tree.

The grub is legless, with a swollen median; the head is armed with strong mandibles. They reach a size of more than 40 to $50 \mathrm{~mm}$ before pupation. Mainly the grubs damage the palms. The grub stage lasts about two months.

Once mature, the grubs form an oval cocoon (approximately $80 \times 35 \mathrm{~mm}$ ) within the destroyed tissue of the tree. Inside the cocoon, the grub pupates. The thick and strong cocoon protects the tender pupa inside. Pupation occurs generally outside the trunk, at the base of the palms, it could also take place inside the crown. The pupal stage lasts three weeks. Lifecycle is completed in three months.

Rhynchophorus ferrugineus passes over three overlapping generations in a year, all life stages can be present within the same palm tree. Generally the adult weevils present in a palm will not move to another one while they can feed on it. All stages of $R$. ferrugineus are well protected by nature.

The external symptoms of attack include the presence of small holes on the stem, oozing out of brown viscous liquid, extrusion of chewed up fibers, longitudinal splitting of leaf bases, yellowing and wilting of leaves of the inner and middle whorl (Abraham et al., 
1998). Later in the infestation process the presence of grubs can be detected through the occurrence of tunnels on the trunk and at the bases of leaf petioles, and through the presence of frass and plant sap, which oozes from these tunnels. When a palm is severely infested, the stem or crown sometimes breaks off the tree. Late detection of the presence of the weevil constitutes a serious problem in the fight against the pest.

Because $R$. ferrugineus is a concealed tissue borer, symptoms of attack at an early stage of infestation are difficult to detect. However, there is a possibility of detecting physiological changes in infested trees (Bokhari and Abuzuhairah, 1992).

In India, 6.9 percent of the coconut palms were infested in Kerala (Abraham et al., 1989) and 11.65 per cent of the young coconut palms (5-10 years old) in Tamil Nadu (Sekhar, 2000). But as mentioned earlier, the date palm yield was reduced by 14 times in areas of its recent introduction.

Rhynchophorus ferrugineus attacks a variety of palms (Nirula, 1956; Lever, 1969; Esteban-Duran et al., 1998a,b; Murphy and Briscoe, 1999) such as betel nut palm, Areca catechu; sugar palm, Arenga pinnata (=Arenga saccharifera); palmyra palm, Borassus flabellifer, fish tail palm, Caryota cumingii; giant mountain fish tail palm, Caryota maxima; Caryota sp.; coconut palm, Cocos nucifera; burl palm, Corypha elata; gibang palm, Corypha gebanga; Corypha sp.; oil palm, Elaeis guineensis; ribbon fan palm, Livistona decipiens; Livistona sp., sago palm, Metroxylon sagu; mangrove palm, Nypa sp.; thorny palm, Oncosperma sp.; royal palm, Oreodoxa regia; Cannary island date palm, Phoenix canariensis; Indian date palm, Phoenix dactylifera; Phoenix sp.; silver date palm, Phoenix sylvestris; royal palmetto palm, Sabal umbraculifera (=Corypha umbraculifera); wind mill palm, Trachycarpus fortunei and fan palm, Washingtonia sp. in a wide geographical area, where these are cultivated.
It also attacks century plant, Agave americana and sugarcane, Saccharum officinarum in some countries.

In India, (laboratory studies) coconut culitivar Chowghat Green Dwarf was most preferred for egg laying by $R$. ferrugineus while Malayan Yellow Dwarf was least preferred (Faleiro and Rangnekar, 2001a), hybrid- Tall x Dwarf was most susceptible and Assam Green Tall (Kampura) least (Mazumder, 1995). In Saudi Arabia, the variety 'Khalas' was found to be more susceptible to $R$. ferrugineus attack (Anonymous, 1998). In Pakistan, $R$. ferrugineus attacked date palm varieties in the following decending order-Aseel (21.41\%) followed by Khurmo (14.5\%), Hawawari $(14.25 \%)$, Karbalain (10.25) and Kupro (6.16\%) (Baloch et al., 1994).

Rhynchophorus ferrugineus can breed in a wide range of climates and this is largely because the grubs feed protected within their host palms (Wattanapongsiri, 1966). Several generations can be passed in the same host tree before the tree collapses (Rajamanickam et al., 1995; Faghih, I996). In addition, in the Middle East, the bulk and quick movement of date palm offshoots as planting material has led to the rapid spread of the pest (Abraham et al., 1998).

In Goa along the West coast of India the period between September and November coinciding with the decline of the Southwest monsoon was favourable for high activity of the adult weevils. However, $R$. ferrugineus was found to be least active during high rainfall months of June and July (Faleiro and Rangnekar, 2001b). In AI Hassa, Saudi Arabia weevil activity was high during April- May and also during October-November. However, weevil activity was low during August and January at the peak of summer and winter, respectively (Anonymous, 1998).

Rhynchophorus ferrugineus was normally a rare and local insect in south India (Nirula, 
1956). Generally, the weevil population is high in managed and commercial plantations than in a natural habitat. In natural habitat the chances of injury are less, natural enemies are protected and ground cover of nectar and pollen bearing plants available which enhances the efficiency of natural antagonist. The excessive use of insecticides is also likely to limit the activity of natural enemies in plantations. The general absence of natural enemies in the date palm plantations in the countries of the Middle East would explain why the $R$. ferrugineus has had a particularly devastating impact in this region.

The basic life cycles of Rhynchophorus spp. (Wattanapongsiri, 1966) as well as $D$. borassi, M. hemipterus, $R$. obscurus and $P$. distortus are similar. Larvae bore into the palms and after several instars develop into adults in about 2 months (Giblin-Davis et al., 1989, Napompeth et al., 1972, Watananpongsiri, 1966). Larvae of Rhynchophorus spp., $\quad D$. borassi, $\quad M$. hemipterus, $R$. obscurus and $P$. distortus appear to inhabit slightly different niches in palms, with Rhynchophorus spp. preferring the crown and/or stem (Wattanapongsiri, 1966; Giblin-Davis and Howard, 1989;); D. borassi lives in tissues of coconut inflorescence and stem (Gerber et al., 1990; Wattanpongsiri, 1966); and M. hemipterus, $R$. obscurus and $P$. distortus petioles and stem periphery, sometimes entering the crown (Giblin-Davis $e t$ al., 1996a; Halfpapp and Storey, 1991). The last instar larvae of these weevils move to the petioles or to the rind of the stem to prepare a cocoon from coarse fibers and become a prepupa, pupa, and adult within several weeks (Wattanapongsiri, 1966; Vaurie, 1966). As the borer damage from most of these species accumulates, fermentation volatiles increase and attract more adults.

Rhynchophorus bilineatus is essentially a Melanesian species (Murphy and Briscoe, 1999). However, it has been recorded from Papua New Guinea, Solmon islands, Indonesia (eastern islands and Papua Prvince) and also from Malaysia (Sarawak). It has been recorded from coconut, Metroxylon armicarum and
Metroxylon solomenense. M. solomenense is the preferred host for breeding of $R$. bilineatus. In Papua New Guinea grubs of $R$. bilineatus produced on Metroxylon palms are considered as delicacy and serve as good source of protein (Mercer and Bukkens, 1997).

Palmetto weevil, Rhynchophorus cruentatus is perhaps the largest weevil in North America measuring 1.9 to $3.0 \mathrm{~cm}$ (from the tip of the rostrum to end of the pygidium). Adults of $R$. cruentatus vary in color from solid black to almost completely red with a variable black pattern. Males and females can be distinguished by the surface of the rostrum. The rostrum of males is covered with tiny bumps while females have a smoothand shiny rostrum. $R$. cruentatus adults are active fliers and can be found throughout the year in Florida. However, adult activity is usually more noticeable in the late spring and early summer months. When not flying in search of a host palm, adults hide between the leaf bases and stems of healthy palms presumably to conserve water within their bodies. $R$. cruentatus preferred high relative humidity, suggesting that this weevil possesses hygroreceptors to locate moist harborage sites (Weissling and Giblin-Davis, 1993a). Its current distribution range extends from the coastal plains of South Carolina through the Florida Keys, and west into coastal Texas. It is the only species of palm weevil in the continental United States attacking severely wounded and dying trees. Of late it has emerged as a serious pest of stressed nursery and transplanted palms.

The female lays an average of 207 eggs in her lifetime in the bases of leaves or in wounds in a dying host palm. Eggs hatch in about three days. The hatching grubs begin to feed on palm tissue. As they molt (grow) the grubs feed primarily in the soft tissue surrounding the apical meristem.

The grubs are legless and creamy to yellowish in color. Their prominent head is dark brown and very hard. Mature grubs can be quite large, some weighing about six grams. 
Grubs of palm weevils are considered a delicacy in some countries.

Mature grubs migrate to the periphery of the stem or petioles and prepare a cocoon from palm fibers. After surrounding themselves with the cocoon, the larvae enter a prepupal stage and then a pupal stage. After a few weeks, an adult emerges from the pupal case and may immediately break free of the cocoon or wait within the cocoon for several days before emerging.

The entire life cycle, from egg to adult, takes about 84 days. Adults may live for several weeks (up to 26 weeks in captivity).

The symptoms of $R$. cruentatus infestation vary, but commonly involve a general, often irreversible decline of younger leaves. In palm species with upright leaves, such as the Canary Island date palm, the older leaves begin to droop during the early stages of infestation but quickly collapse thereafter.

As the infestation progresses, the larval feeding damage by grubs and associated rot is so severe that the top of the palm falls over and grubs, cocoons, and even adults are found within the crown region.

Early detection of weevil infestation is difficult, and treatment even in the early stages of infestation may be too late to save the tree. The abundance of adult palm weevils is affected by seasonal changes.

The primary food source for $R$. cruentatus is stressed or damaged cabbage palmetto palm (Sabal palmetto), a palm native to the southeastern U.S. Saw palmetto, Serrenova repens is an alternate host and it also sometimes attack other palms such as Cannary island date palm, Phoenix canariensis; date palm, $P$. dactylifera; coastal loulu palm, Pritchardia sp.; fan palm, Washingtonia sp.; royal palm, Roystonea sp.; latin palm, Latania sp.; coconut palm, Cocos nucifera; and fish tail palm, Caryota sp. In undisturbed locations, palms are rarely observed with $R$. cruentatus infestations. Trees stuck by lightening have been observed with subsequent weevil infestations.

Rhynchophorus spp. seeks harborage in leaf axils of healthy palms (Weissling and Giblin-Davis, 1993) and moist fermenting garbage (Chittenden, 1902). Dynamis borassi usually prefers fresh tissue. In Florida, $R$. cruentatus (Weissling et al., 1994a) and M. hemipterus (Peña et al., 1995) are more abundant in spring, before the onset of the rainy season.

The American palm weevil, $R$. palmarum is a serious pest on coconut and oil palm in the Neotropical region (Wattanapongsiri, 1966). Weevils attack healthy coconut palms but in oil palm mechanical injury or rot usually precede weevil attack (Chinchilla, 1988). Grubs cause extensive tunneling in the trunk or the whorl (Griffith, 1987). R. palmarum is the major known vector of red ring disease caused by nematode, Bursaphelenchus (Rhadinaphelenchus) cocophilus (Cobb) Baujard (Cobb, 1922; Tidman, 1951; Hagley, 1963: Martyn, 1953; Griffith, 1967, 1978, 1987; Gerber et al., 1990a; Chinchilla et al., 1993; Oehlschlager et al., 1993a).

In oil palm, infection by other mechanisms such as via nematode carrying harvest knives or soil (Fenwick, 1968) is considered insignificant in comparison to inoculation by the weevil (Schuiling and Dinther, 1981; Chinchilla, 1988). Red ring symptoms become evident after 2-3 months of infection and nematicidal treatments failed to cure the palms. However, low percentage of recuperation with systemic nematicide treatment occurs when symptoms are solely of the little leaf type (Chinchilla, 1988). $R$. palmarum populations appear to peak at the end of the rainy season and throughout most of the dry season in coconut plantations in Trinidad (Hagley, 1963), and in the dry season in oil palm plantations in Brazil (Schuiling and Dinther, 1981), Costa Rica (Morales and 
Chinchilla, 1990) and Honduras (Chinchilla et al., 1990).

The African palm weevil Rhynchophorus phoenicis causes damage in Africa particularly to young oil palms. Boring by the grub into the crown or root bulb of a young palm causes yellowing of the leaves, while boring close to the growing point is lethal to the palm (Gries et al., 1993).

The silky cane weevil, Metamasius hemipterus was accidentally introduced into Dade County, Florida in the early 1980's. It is an important pest of sugarcane, other plants and palms, in the Neotropics (Alpizar, 2002). Adults are attracted to and lay eggs in palm sheaths, petioles, or stems. Within the host, larvae develop into adults in less than two months. The weevil adults appear to be attracted to palms by odors emanating from small wounds created by pruning of leaves. Normally $M$. hemipterus attack is not lethal, but the stress created by the infestation makes the palms susceptible to successful attack by $R$. cruentatus.

Among other species (Mariau, 2002), Amerrhinus ynca attacks Brazilian coconuts. Adults are yellow with black points. They lay their eggs in the stems of young palm trees. In cases of severe attack these palms become yellow and break.

Homalinotus coriaceus attacks coconuts in Brazil, between the States of Bahia and Paraiba (Bondar, 1940). The adult is black, and about 20-25 mm long. Eggs are laid at the base of the inflorescence. If the inflorescence is still young, the damage results in rapid and total rot. More often, tunnels are bored in the periphery of the rachis of the inflorescence. This weakens the rachis, which may break when it carries many fruits. Otherwise, the nuts may fall off as a result of insufficient nourishment. The pupal stage is passed in a small excavation made by the larva in the surface of the stem at the base of the rachis. Dwarf coconuts are much more susceptible than talls.

The black adults of South American species, Rhinostomus barbirostis are about 30$40 \mathrm{~mm}$ long (excluding its very hairy and long rostrum). Being nocturnal, in the daytime they may be found in the grass at the foot of the tree or, more often, in the axils of old leaves (Mariau, 2002). Unlike Rhynchophorus, $R$. barbirostis do not need wounds in the stem to lay their eggs, which are often deposited on small uneven parts of the healthy coconut palm. On some of them very great quantities of eggs can be observed, up to more than 100 on a band $10 \mathrm{~cm}$ wide. The stem is bored through in all directions, causing a general weakening of the tree, and breakage in case of gusty winds. Attacks may vary between one coconut palm and another. The most serious attacks by these insects have been reported from Brazil, especially from the State of Sergipe. Rhinostomus afzelii (Gyllenhal) is distributed in Africa.

\section{Biological control}

Studies conducted by various workers in different countries have shown that the community of natural enemies associated with palm weevils includes nematodes, fungi, virus, bacteria, insects and mites (Table 3 ). 
Table 3. Natural enemies of Rhynchophorus species*

\begin{tabular}{|c|c|c|c|}
\hline Species & R. ferrugineus & R. bilineatus & R. palmarum \\
\hline $\begin{array}{l}\text { Nematodes } \\
\text { Diplogasteridae } \\
\text { Diplogasteritus } \mathrm{sp} . \\
\text { Mononchoides } \mathrm{sp} . \\
\text { Entaphelenchidae } \\
\quad \text { Praecocilenchus ferruginophorus (Rao and Reddy) } \\
\text { Praecocilenchus rhaphidophorus ( Poinar) } \\
\text { Heterorhabditidae } \\
\text { Heterorhabditis indica (Poinar, Karunakar \& David) } \\
\text { Heterorhabditis } \text { sp. } \\
\text { Steinernematidae } \\
\text { Steinernema abbasi Elawad, Amad \& Reid } \\
\text { Steinernema } \mathrm{sp} \\
\text { Rhabditidae } \\
\quad \text { Rhabditis sp. } \\
\text { Teratorhabditis palmarum Gerber \& Giblin-Davis }\end{array}$ & $\begin{array}{l}\mathrm{v} \\
\mathrm{v} \\
\mathrm{v}\end{array}$ & $\mathrm{V}$ & $\begin{array}{l}\mathrm{v} \\
\mathrm{v} \\
\mathrm{v}\end{array}$ \\
\hline $\begin{array}{l}\text { Bacteria } \\
\text { Bacillaceae } \\
\text { Bacillus sphaericus Meyer and Neide } \\
\text { Micrococcaceae } \\
\quad \text { Micrococcus sp. } \\
\text { Pseudomonadacae } \\
\text { Pseudomonas aeruginosa (Schroeter) Migula }\end{array}$ & $\mathrm{v}$ & & $\mathrm{v}$ \\
\hline $\begin{array}{l}\text { Fungi } \\
\text { Hyphomycetes } \\
\text { Metarhizium anisopliae (Metschnikoff) Sorokin } \\
\text { Beauveria bassiana (Balsamo) Vuillemin }\end{array}$ & $\begin{array}{l}\mathrm{v} \\
\mathrm{V}\end{array}$ & $\mathrm{v}$ & \\
\hline $\begin{array}{l}\text { Insects } \\
\text { Reduviidae } \\
\text { Platymeris laevicollis Distant } \\
\text { Forficulidae } \\
\text { Chelisoches morio (Fabricius) } \\
\text { Staphilinidae } \\
\text { Xanthopygus cognatus Sharp } \\
\text { Sarcophagidae } \\
\text { Sarcophaga fuscicauda } \text { Bottcher } \\
\text { Scoliidae } \\
\text { Scolia erratica } \text { Smith } \\
\text { Tachinidae } \\
\text { Paratheresia menezesi Townsend } \\
\text { Paratheresia rhynchophorae (Blanchard) }\end{array}$ & $\mathrm{v}$ & & v \\
\hline $\begin{array}{l}\text { Mites (ectoparasites?) } \\
\text { Hypoaspidae } \\
\text { Hypoaspis sp. } \\
\text { Pymotidae } \\
\text { Tetrapolypus rhynchophori Ewing }\end{array}$ & $\begin{array}{l}\mathrm{v} \\
\mathrm{v}\end{array}$ & & \\
\hline $\begin{array}{l}\text { Viruses } \\
\text { Cytoplasmic polyhedrosis virus }\end{array}$ & $\mathrm{V}$ & & \\
\hline Yeast from the haemolymph & $\mathrm{v}$ & & \\
\hline
\end{tabular}

* Reported by Burkill (1917), Iyer (1940), Nirula (1956), Abraham and Kurian (1975), Moura et al. (1994), Rao and Reddy (1980), Peter (1989), Gopinadhan et al. (1990), Shamseldean and Abd Elgawad (1994), Bedford (1974), Abbas et al. (2001), Ghazavi and Faghih (2002), Bano and Rajendran (2003), Salma et al. (2004), Banarjee and Danger (1995), Danger (1997), Hanounik (1998), Bedford (1974), Quezada et al.(1969), Prior and Arura, 1985, Poinar (1969). 
A bacterium, Pseudomonas aeruginosa was isolated from naturally infected specimens of $R$. ferrugineus collected in Kerala, India (Banerjee and Dangar, 1995). Entomopathogenic fungus, Metarhizium anisopliae was isolated from $R$. bilineatus and other beetles in Papua New Guinea (Prior and Arura, 1985). A cytoplasmic polyhedrosis virus (CPV) specific to $R$. ferrugineus (Gopinadhan et al., 1990) and unidentified yeast (Dangar, 1977) were recorded in Kerala, India. Gerber and Giblin-Davis (1990) reported the presence of three nematode species in the bodies of adult $R$. palmarum but their pathogenicity to the weevils was unclear. Praecocilenchus rhaphidiophorus was recorded parasitizing $R$. bilineatus in New Britain in 1969 (Poinar, 1969) while $P$. ferruginophorus was recovered from $R$. ferrugineus in India in 1980 (Rao and Reddy, 1980).

Scoliid Scolia erratica Smith (Burkill, 1917) and furficulid predator, Chelisochcs morio- a common predator in the crown of coconuts in Kerala, India were recorded from $R$. ferrugineus (Abraham et al., 1973). Nymphs and adults of the predator consumed 5.3 and 8.5 eggs or 4.2 and 6.7 grubs of $R$. ferrugineus. Staphilinid, Xanthopygus cognatus was recorded feeding on $R$. palmarum in Al Salvador (Quezada et al., 1969).

Gregarious tachinid parasitods, Paratheresia rhynchophorae (Guimaraes et al., 1977) and P. menezesi (Moura et al., 1993) were reported from $R$. palmarum. In oil plantations in Bahia, Brazil, $P$. menezesi parasitised $50 \%$ of $R$. palmarum. Mere presence of the parasitoid $P$. menezesi was generally insufficient for controlling serious outbreaks of Amerrhinus ynca (Moura et at., 1994). Sarcophagid Sarcophaga fuscicauda was reported to attack the adults of $R$. ferrugineus in India (Iyer, 1940).

In India, two mite species, Hypoaspis sp. and Tetrapolypus rhynchophori have also been recorded infesting the adult beetles (Nirula, 1956; Peter, 1989), but the status of these species as parasites is uncertain. Apart from above groups, lizards, toads and birds also feed on adults.

The above account shows that systematic and exensive search for new natural enemies in all the distribution zones of palm weevils is necessary. It seems to be appropriate to conduct more studies on tachinid parasitoids, the efficient one could be established in different countries. Also entomopathogens need extensive studies in different countries.

\section{Management stretegies}

Till the 1980s $R$. ferrugineus management relied mostly on the use of insecticides. However, there is now a strong emphasis on the development of integrated pest management (IPM) (Abraham and Kurian, 1975; Abraham et al., 1989; Murphy and Briscoe, 1999) including efficient use of pheromone traps and biological control rather than insecticides alone.

For the management of $R$. ferrugineus in India the recommendations given from time to time incude- surveillance of the pest, avoiding any injury to palm, sealing the injuries with coal tar + carbaryl or slurry of clay or soil prepared with $5 \mathrm{gm}$ carbaryl $50 \mathrm{WP}$, maintaining plant and field sanitation, when green leaves are to be cut it can be done leaving a petiole length of $120 \mathrm{~cm}$, trapping adult weevils, treating the crown of bud rot diseased or Oryctes attacked palms which attract the weevil with a combination of fungicide and insecticide, leaf axil filling with of carbaryl (sevidol 8G) 25g and sand $200 \mathrm{~g}$, curative methods include - injection of $0.1 \%$ endosulfan/dichlorvos or $1 \%$ carbaryl by drilling a downword slanting hole into the stem at about $1.5 \mathrm{~m}$ above ground level and pluging with clay (before treating the palm, the nuts are harvested and a waiting period of 45 days observed for next harvest of nuts), log trapping with fermented toddy, mud pot with molasses and placement of pheromone+banana or 
sugarcane or tender coconut stalk pieces, and finally educating the farmers and agricultural workers on palm weevil management (Abraham and Kurian, 1975); Abraham et al., 1989; Anonymous, 1998; Nair et al., 2002).

In the laboratory 0.1 per cent cypermethrin (Abo-EI-Saad et al., 2001) and 0.2 per cent primiphos methyl or 0.36 per cent oxydemeton methyl (Ajlan et al., 2000) were most effective against $R$. ferrugineus.

The insecticides are administrated into the affected palm tissue as curative treatment. Slanting holes, 2 to $3 \mathrm{~cm}$ in diameter and 15 $\mathrm{cm}$ deep are made around the affected part using a hollow pointed iron pipe. The insecticide poured into these holes kills the grubs and other stages of the insect inside the trunk (Anonymous 1995). Different insecticides recommended for stem injection to treat $R$. ferrugineus infested palms include pyrocone-E-1\% (pyrethrins-piperonyl butoxide combination) (Nirula, 1956), carbaryl-1\% (Mathen and Kurian, 1967), 0.2\% fenthion (Rao et al., 1973), 0.2 per cent trichlorphon (Abraham et al., 1975), $10 \mathrm{ml}$ of monocrotophos, or the same volume of a combination of monocrotophos and dichlorvos $(5+5 \mathrm{ml})$ (Muthuraman, 1984). Injection method was successfully carried out in United Arab Emirates by EI-Ezaby (1997) with carbosulfan, pirimiphos-ethyl and dimethoate. Imidachloprid and fipronil have also shown promise. Root feeding with $10 \mathrm{ml}$ monocrotophos $+10 \mathrm{ml}$ water was also effective in India (Rao et al., 1989; Nair et al., 2002). Carbaryl was effective in Indonesia when applied regularly at two-month interval (Soenardi and Hariadi, 1978).

Phostoxin tablets (aluminium phosphide) applied at a rate of at $0.5-1$ tablet/tree were effective in controlling larvae, pupae and adults of $R$. ferrugineus on coconut (Rao et al., 1973). Muthuraman (1984) alternatively used two 3-g Celphos (aluminium phosphide) tablets crushed and placed in holes in date palm. All holes were then sealed with a paste of cement and copper oxychloride to contain the highly toxic phosphine gas released by the tablets. Soaking of the trees with insecticides such as chlorpyriphos, endosulfan, fenitrolthion, diazinon and methidathion has also been attempted.

The technique of multiplication and release of sterile male weevils as first demonstrated by Rahalkar et al. (1973) could also play an important role in $R$. ferrugineus management programmes.

\section{Semiochemicals in the management of palm weevils}

Observation that adults of $R$. cruentatus were attracted to nitrocellulose lacquer-based automobile paint in Sanford, FL (Bare, 1929) provided a stimulus for research on semiochemicals. Semiochemicals are the chemicals that act as signals between organisms, aggregation pheromones serve as intraspecific transitory signals, whereas kairomones, such as host-plant volatiles, act interspecifically with the receiver benefiting (Dusenbery, 1992). Semiochemicals isolated from Rhynchophorus spp. are presented in Table 4.

For attraction of adult palm weevils (Rhynchophorus palmarum, $R$. phoenicis, $R$. ferrugineus, Dynamis borassi, Metamasius hemipterus, Rhabdoscelus obscurus, and Paramasius distortus) split petioles of different palms such as sugar palm, palmyra palm, fish tail palm, coconut palm, burl palm, gibang palm, African oil palm, oil palm, ribbon fan palm, sago palm, mangrove palm, thorny palm, date palm, palmetto palm and screw pine; cut pieces of sugarcane, aloe and, banana and pineapple fruits were used alone in combination of synthetic kairomones and in combination with different aggregation pheromones.The attractiveness of the plant tissue compounds increased by decomposition of the plant material. 
Table 4. Semiochemicals of Rhynchophorus spp.

\begin{tabular}{|c|c|c|}
\hline Species & Semiochemical & Reference \\
\hline Rhynchophorus bilineatus Montrouzier & 4S5S-ferrugineol & Oehlschlager et al. (1995) \\
\hline Rhynchophorus cruentatus Fabricius & $\begin{array}{l}\text { 5me-octan-4-ol } \\
\text { 3S4S-3me-octan-4-ol } \\
\text { 4S5S-5me-octan-4-ol } \\
\text { S-ethyl lactate } \\
\text { ethyl isobutyrate } \\
\text { ethyl butyrate } \\
\text { ethyl alcohol }\end{array}$ & $\begin{array}{l}\text { Weissling et al. }(1994 \mathrm{c}) \\
\text { Perez et al. }(1994) \\
\text { Giblin Davis et al. (1994b) }\end{array}$ \\
\hline Rhynchophorus ferrugineus Olivier & $\begin{array}{l}\text { ethyl acetate } \\
\text { 2methoxy-4vinylphenol } \\
\text { gamma-nonanoic } \\
\text { lactone } \\
4 \text { S5S-ferrugineol } \\
5 \mathrm{OH} \\
\text { ferrugineol } \\
4 \mathrm{me}-9-5 \mathrm{Kt}\end{array}$ & $\begin{array}{l}\text { El Sebay (2003) } \\
\text { Gunawardena } \text { et al. (1998) } \\
\text { Gunawardena and Herath (1995) } \\
\text { Hallett et al. (1993a) }\end{array}$ \\
\hline Rhynchophorus palmarum Linnaeus & $\begin{array}{l}\text { 3me-4OH } \\
\text { 2me-4OH } \\
\text { acetoin } \\
\text { isobutyl acetate } \\
\text { 2,3-4diol } \\
\text { 2phenylethanol } \\
\text { ethyl alchohal } \\
\text { ethyl acetate } \\
\text { phenol } \\
\text { guaiacol } \\
\text { veratrole } \\
\text { 6-2Kt } \\
\text { 9-2Kt } \\
\text { 7-2Kt } \\
\text { menthone } \\
\text { beta-phellandrene } \\
\text { ethyl octanoate } \\
\text { ethyl acetate } \\
\text { E2-6me-hepten-4-ol } \\
\text { ethyl alchohal } \\
\text { 5Hy } \\
\text { 6Ald } \\
\text { isopentyl acetate } \\
\text { 3me-4OH } \\
\text { E2-6me-hepten-4-ol } \\
\text { E2-6me-hepten-4-ol }\end{array}$ & $\begin{array}{l}\text { Rochat et al. (2000) } \\
\text { Jaffe et al. (1993) } \\
\text { Rochat et al. (1991b) } \\
\text { Oehlschlager et al. (1992a) } \\
\text { Rochas }\end{array}$ \\
\hline Rhynchophorus phoenicis Fabricius & $\begin{array}{l}\text { ethyl propionate } \\
\text { 3S4S-3me-octan-4-ol } \\
\text { 3me-octan-4-ol }\end{array}$ & $\begin{array}{l}\text { Gries et al. }(1994) \\
\text { Perez et al. } 1994) \\
\text { Gries } \text { et al. }(1993)\end{array}$ \\
\hline Rhynchophorus vulneratus Panzer & $\begin{array}{l}\text { 4S5S-ferrugineol } \\
\text { ferrugineol } \\
4 \mathrm{me}-9-5 \mathrm{Kt}\end{array}$ & Hallett et al. (1993a) \\
\hline
\end{tabular}


Fermented sap exuding from dead or wounded palmetto and Cannary islands date palms (Sabal palmetto and Phoenix canariensis) is highly attractive to $R$. cruentatus (Chittenden, 1902). Attractiveness of chopped, fermenting, $S$. palmetto crown and stem tissue peaks 24-72 hours after cutting, whereas cut surfaces of felled palms remain attractive for 35 days (Weissling et al., 1992). Moist fermenting (stem) tissues from various palm species, fruits, sugarcane, pineapple, and molasses (plus water) are similarly attractive to palm weevils (Diegado and Moreno 1986, Giblin-Davis et al., 1994b). Plant tissues (stem of saw palmetto palm, Serrenova repens) or molasses with minimal moisture content are significantly less attractive to $R$. cruentatus and M. hemipterus, respectively (Giblin-Davis et al., 1994a, 1996a). Early fermentation volatiles of moist and stressed, damaged, or dying host plant tissues with high sugar content obviously provide olfactory cues to attract palm weevils.

The "palm esters" or plant kairomones such as ethanol, ethyl (S)-(-)-lactate, ethyl acetate, ethyl butyrate, ethyl isobutyrate, ethyl propionate, ethyl acetate, hexanal, isoamylacetate, isopentanol and pentane were isolated and evaluated individually, in different mixtures and in combination with different aggregation pheromones. Plant kairomones strongly enhance pheromone attractiveness. Among the volatiles identified, ethanol was shown to be attractive; in addition to isoamylacetate (Hagley, 1965), and known to be present in pineapple and banana. Pure ethanol or isoamyl-acetate was as attractive as or even more attractive than natural plant tissue (i.e., pineapple vs. isoamyl-acetate.

Coconut plants contain water, $\mathrm{CO} 2$, ethyl acetate, pentane, hexanal, isopentanol, and ethanol. Fruits of pineapple produce ethanol and ethyl acetate (Jaffe et al., 1993). A mixture of $68 \%$ ethanol, $27 \%$ ethyl acetate, and 5\% pentane was found to be as attractive as natural plant tissue. Jaffe et al. (1993) observed that ethanol and ethyl acetate in proportion of
70:30, as found in coco plants, was the most attractive two compound mixtures for the weevils. The proportion of ethanol vs. ethyl acetate changed during decomposition of the material, reaching a proportion of 7:3 after three days of decomposition and remained relatively constant up to 9 days. A complex mix of ethanol, ethyl acetate, pentane, hexanal, isolamyl-acetate, and/or isopentanol serve as a short-range orientation cue to fresh wounds on the plant but additional host odor, attracting weevils from a distance is to be discovered.

In most of the countries sugarcane (250 to $500 \mathrm{~g}$ ) is used as food bait in pheromone traps. In the Middle East, date stem or date fruit itself is the food bait in the traps. In India, banana was efficient food bait (Nair et al., 2000). Coconut toddy is used as food bait in Sri Lanka. It is not possible to get some or all of these natural synergists in all places and during different times of the year. Hence, coconut or any other weevil attractive palm petiole, which is easily available, is commonly used as food bait in pheromone traps in palm plantations. It is also essential to replace the food bait in the trap every week or at nine days interval to maintain the efficacy of the pheromone trapping system.

Historically attracting and killing the weevils formed an important management strategy. A mixture of malt skatole and isoamyl acetate was significantly better than coconut stem tissue as an attractant for both sexes of $R$. palmarum (Hagley, 1965). In Sri Lanka and Trinidad metal traps filled with coconut petioles were effective in attracting the weevils (Maharaj, 1973). However, in India coconut logs proved more effective than metal traps (Kurian et al., 1979). Coconut logs treated with toddy (1litre), yeast $(5 \mathrm{~g})$ and acetic acid $(5 \mathrm{ml})$ attracted significantly more number of adult weevils as compared to other food attractants (Kurian et al., 1984).

As mentioned above the early research provided evidence that general fermentation volatiles, such as ethanol, appeared attractive 
to Rhynchophorus weevils (Gunatilake and Gunawardena 1986, Hagley 1965). The recent discovery of aggregation pheromones, which greatly enhance attractiveness of plant tissues, facilitated identification of individual palm kairomones (Giblin-Davis et al., 1994b, 1996a, Gries et al., 1994, Jaffé et al., 1993, Perez et al., 1995).

Palm weevils (Rhynchophorus palamrum, $R$. phoenicis, $R$. bilineatus, $R$. ferrugineus Dynamis borassi, Metamasius hemipterus, Rhabdoscelus obscurus, and Paramasius distortus) use male-produced aggregation pheromones for intraspecific chemical communication (Giblin- Davis et al., 1996a). Males of the palm weevils produce several volatile pheromone related compounds. They are classified as aggregation pheromones since only males produce them but attract both males and females.

Pheromones comprise 8,9 , or 10 carbon, methyl-branched, secondary alcohols. (4S, 5S)-4-methyl-5-nonanol (ferrugineol) (Hallett et al., 1993a) is the major aggregation pheromone for $R$. ferrugineus, $R$. bilineatus, $M$. hemipterus, and $D$. borassi and a minor component for $R$. palmarum (Giblin- Davis et al., 1996a). (5S, 4S)-5-methyl-4-octanol (cruentol) (Perez et al., 1994; Weissling et al., 1994c); (3S, 4S)-3-methyl-4-octanol (phoenicol) (Perez et al., 1994), and (4S, 2E)6-methyl-2-hepten-4-ol (rhynchophorol) (Rochat et al., 1991b; Oehlschlager et al., 1992a; Jaffe et al., 1993) are the main aggregation pheromones for $R$. cruentatus, $R$. phoenicis, and $R$. palmarum, respectively (Giblin-Davis et al., 1996a). 4-methyl-5nonanol is the male produced aggression pheromone of $D$. borassi (Giblin-Davis et al., 1997).

For field utilization, nineteen litre capacity plastic bucket was modified by cutting holes in the bottom and entry slots in the sides and top, a device placed to release $3 \mathrm{mg}$ per day of synthetic pheromone, 15 pieces of halved sugar cane stalks that had been immersed in a suspension containing $1.5 \mathrm{cc} / \mathrm{l}$ carbofuran, and this bucket hung on palms at about $1.7 \mathrm{~m}$ above the ground formed a sustained pheromone based trapping system for $R$. palmarum on oil palm in Latin America (Oehlschlager et al., 1993a). Captured weevils could also be killed by sugarcane stalks treated with other pesticides such as carbaryl and lannate (Oehlschlager et al. 1993a) or with soapy water in the bottom of traps (Weissling et al., 1992, 1994b). Based on this experience bucket traps containing pheromone lure and an insecticide treated food bait is widely used to manage $R$. ferrugeneus both in date and coconut plantations (Faleiro et al., 1998). Five litre capacity high-density polyethylene buckets $(22 \mathrm{~cm}$ diameter and $19 \mathrm{~cm}$ height) are used as pheromone traps. The lid of the bucket is kept $4 \mathrm{~cm}$ raised above the bucket for entry of the weevils. The bucket is wrapped with jute sack to provide grip to the attracted weevils and facilitate their entry in to the trap. The bucket trap is filled one-fourth with synergist bait consisting $100 \mathrm{~g}$ mashed banana $+2 g$ yeast $+2 g$ carbaryl mixed in one litre of water. The pheromone dispenser containing 100 micro litre i.e.78.5mg is placed inside a plastic sachet and suspended at the centre of the bucket with the help of a wire. One is placed at $1.5 \mathrm{~m}$ height from the ground level per hectare at strategic places (Abraham and Nair, 2001; Faleiro and Satarkar, 2003; Mayilvaganan et al., 2003). A new pheromone sachet Ferrolure + $800 \mathrm{mg}$ is widely used in surveillance and mass trapping programmes through out the world. In India (Goa) this lure once used in coconut plantations is capable of attracting the pest for five to six months in the field (Faleiro and Rangnekar, 2001c). In Saudi Arabia, field studies on the longevity of pheromone lures revealed that the pheromone (ferrolure $700 \mathrm{mg}$ ) exhausted in three months during summer as compared to the winter months when lures lasted for about five months. Also, ferrolure and ferrolure+ (with additive) released the same quantity of the chemical into the environment under shaded conditions, but when traps had to he exposed to sunlight, ferrolure+ lasted longer than ferrolure (Faleiro et al., 1999). In coconut, highest numbers of $R$. ferrugineus weevils were 
captured in Indonesia when traps were placed at ground level (Hallett et al., 1999). But there are chances of disturbing the traps by ground dwelling predators.

Weevil captures from date and coconut plantations in Saudi Arabia (Al Hassa) and India (Kerala, Goa), respectively have been reported to be female dominated (Abraham et al., 1999; Vidyasagar et al., 2000; Abraham et al., 2000b). Adult female $R$. ferrugineus attracted to pheromone traps in coconut gardens of India were also found to be young, fertile and gravid (Faleiro, 2000; Faleiro et al., 2003). This indicates that at present ferrugineol based pheromone traps not only monitor $R$. ferrugineus activity, but also suppresses its build up in the field when used in mass trapping programmes. Continuous mass trapping of $R$. palmarum in oil palm in Costa Rica for 17 months significantly reduced weevil captures from 32.4 weevils per trap to 6.4 per traps (Oehlschlager et al., 1995b). Mass trapping of adults of $R$. ferrugineus together with other management tactics over a period of four years (1994 to 1995) significantly reduced infestation levels in date palm plantations of Saudi Arabia (Abraham et al., 2000a; Vidyasagar et al., 2000).

\section{Conclusions}

Weevils are serious pests of coconut palms, oil palms and date palms. Rhynchophorus ferrugineus is spreading fast. By now it has invaded more than 31 countries in Asia, Africa and Europe. The main ornamental tall palms planted in the gardens and in the streets of the Mediterranean coast cities are date palms. Thousands of them are imported from Egypt each year directly or indirectly into Spain and other European countries. These palms must have a phytosanitary certificate to assure that the plants are weevil free. $R$. ferrugineus could be also a catastrophe in Elche (Spain) where the date grove has been nominated as a World Heritage Site.
There is a need of determining the correct identity of species and strains of palm weevils by adopting traditional morphometrical and advanced DNA-based fingerprinting techniques. Studies are necessary on crop loss assessment, biotypes, behavioral changes in relation to the changing agro-climatic conditions, population dynamics, natural enemies, innovative pheromone trapping methods including use of synthetic food baits, breeding for pest tolerance or resistance palm, introduction of deleterious genes in the pest population, release of sterile male weevils in endemic areas, development of biocontrol techniques, fabrication of a light portable aquistical detector, improvement of insecticide application gadgets are necessary for refining the existing IPM programme. Particular attention is needed in selecting the best tachinid parasitoids and distributing in different areas, alternate palm hosts distinctly more attractive to weevils, and synthesizing the pheromone locally for distribution to coconut palm, oil palm and date palm producers need encouragement. There is a need for co-operative international network research project for indepth studies on weevils.

\section{References}

Abbas, M. S. T., Hanounik, S. B. Mousa, S.A. and Mansour, M. I. 2001.On the pathogenicity of Steinernema abbasi and Heterorhabditis indicus isolated from adult Rhynchophorus ferrugineus (Coleoptera). Int. J. Nematol. 11(1): 69-72.

Abbas, M. S. T., Hanounik, S. B., Mousa, S.A. and Al-Bagham, S.H. 2000. Soil application of entomopathogenic nematodes as a new approach for controlling Rhynchophorus ferrugineus on date palm. Int. J. Nematol. 10(2): 215-218.

Abo-El-Saad, M. M., Ajlan, A. M., Shawir, M. S., Ahdulsalam, K. S. and Rezk, M. A. 2001. Comparative toxicity of four pyrethroid insecticides against red palm weevil, Rhynchophorus ferrugineus F. under laboratory conditions. J. Pest Cont. Environ. Sci. 9(3): 63-76. 
Abraham, V. A. and Kurian, C. 1975. An integrated approach to the control of Rhynchophorus ferrugineus $\mathrm{F}$. the red weevil of coconut palms. In: Proceedings $4^{\text {th }}$ Session of the FAO Technical Working Party on Coconut Production, Protection, Processing. Kingston, Jamaica, September 14-25.

Abraham, V. A. and Nair, S. S. 2001. Evaluation of five insecticides for use in the red palm weevil pheromone traps. Pestology 25(1): 31-33.

Abraham, V. A., Al Shuaibi, M. A., Faleiro, J. R., Abuzuhairah, R. A. and Vidyasagar, P. S. P. V. 1998. An integrated management approach for red palm weevil, Rhynchophorus ferrugineus Oliv., a key pest of date palm in the Middle East. Sultan Qubus Univ. J. Sci. Res., Agric. Sci. 3: 77-83.

Abraham, V. A., Faleiro, J. R., Al-Shuaibi, M. A. and Abdan, S. 2000b. Status of pheromone trap captured female red palm weevil from date gardens of Saudi Arabia. J. Trop. Agric. 39: 197-199.

Abraham, V. A., Faleiro, J. R., Al-Shuaibi, M. A. and Prem Kumar, T. 2000a. A strategy to manage red palm weevil Rhynchophorus ferrugineus Oliv. in date palm Phoenix dactylifera, its successful implementation in AI-Hassa, Kingdom of Saudi Arabia. Pestology 24(12): 23-30.

Abraham, V. A., Faleiro, J. R., Prem Kumar, T. and Al Shuaibi, M. A. 1999. Sex ratio of red palm weevil Rhynchophorus ferrugineus Olivier captured from date plantation of Saudi Arabia using pheromone traps. Indian J. Entomol. 61(2): 201-204.

Abraham, V. A., Koya, K. M. A. and Kurian, C. 1975. Evaluation of seven insecticides for control of red palm weevil Rhynchophorus ferrugineus Fahr. J. Plant. Crops 3(2): 71-72.

Abraham, V. A., Koya, K. M. A. and Kurian, C. 1989. Integrated management of red palm weevil (Rhynchophorus ferrugineus F.) in coconut gardens. Presented at the $7^{\text {th }}$ Symposium on Plantation Crops, Coonoor, India,16-19 October 1986. J. Plant. Crops 16: 159-162.

Abraham, V. A., Kurian, C. and Nayer, N. M. 1973. Chelisoches morio F. (Forficulidae: Dermaptera), a predator on eggs and early instar grubs of the red palm weevil Rhynchophorus ferrugineus F. (Curculionidae : Coleoptera). J. Plant. Crops 1: 147-I52.

Ajlan, A. M., Shawir, M. S., Abo-El-Saad, M. M., Rezk, M. A. and Abdulsalam, K. S. 2000.Laboratory evaluation of certain organophosphorus insecticides against the red palm weevils. Rhynchophorus ferrugineus Olivier. Sci. J. King Faisal Univ. Bas. Appl. Sci. 1(1): 15-26.

Alpizar, M. D. 2002. Elements for the integrated management of weevils (Curculionidae) on palm. ( Elementos para el manejo integrado de los picudos (Curculionidae) del palmito). Manejo Integrado de Plagas y Agroecologia No.65, i-vi.

Anonymous, 1995. Report of the "Expert consultation on date palm pest problems and their control in the Near East". Cairo, Egypt. April 20-26. AI-Ain, UAE, 56 pp.

Anonymous, 1998. Final report of the Indian Technical Team (Part A) - Red palm weevil control project, Ministry of Agriculture and Water, Kingdom of Saudi Arabia, 65 pp.

Baloch, H. B., Rustamani, M. A., Khurd, R. D., Talpur. M. A., Hussain, T. and Shakoori, A. R. 1994. Incidence and abundance of date palm weevil in different cultivars of date palm. Proc. Twelfth Pakistan Congr. Zool. 12: 445-447.

Banerjee, A. and Dangar, T. K. 1995. Pseudomonas aeruginosa, a facultative pathogen of red palm weevil, Rhynchophorus ferrugineus. World J. Microbiol. Biotech. 11(6): 618-620.

Banks, C. S. 1906. The principal insects attacking the coconut palm. Philippines $J$. Sci. 1: 2-3. 
Banu, J. G. and Rajendran, G. 2003. Nematodes associated with red weevil, Rhynchophorus ferrugineus Linn. in Kerala. J. Exp. Zool., India 6(1): 99-100.

Banu, J. G., Rajendran, G. and Subramanian, S. 2003. Susceptibility of red weevil, Rhynchophorus ferrugineus Oliv to entomopathogenic nematodes. Annals Plant Prot. Sci. 11(1): 104-106.

Bare, C. O. 1929. Rhynchophorus cruentatus Fab., the palmetto weevil, attracted to automobile paint. J. Econ. Entomol. 22: 986.

Barranco, P., De La Peña, J. and Cabello, T 1996. El picudo rojo de las palmeras, Rhynchophorus ferrugineus (Olivier), nueva plaga en Europa. (Coleoptera, Curculionidae). Phytoma España 67: 36-40.

Barranco, P., De La Peña, J., Martin, M. M. and Cabello, T. 2000. Rango de hospedantes de Rhynchophorus ferrugineus (Olivier, 1790) y diámetro de la palmera hospedante. (Coleoptera, Curculionidae). Bol. Sanidad Veg. Plag. 26(1): 73-78.

Bedford, G. O. 1974. Parasitism of the palm weevil Rhynchophorus bilineatus (Montroazier) (Coleoptera: Curculionidae) by Praecocilenchus rhaphidophorus (Poinar) (Nematoda: Aphelenchoidea) in New Britain. J. Australian Entomol. Soc. 13: 155-156.

Bokhari, U. G. and Abuzuhairah, R. A. 1992. Diagnostic tests for red palm weevil, Rhynchophorus ferrugineus infested date palm trees. Arab J. Sci. Res. 10: 93-104.

Bondar, G. 1940. Insetas nocivos e mollestias do coqueiro (Cocos nucifera L.) no Brasil Tipogradia , Naval, Salvador.

Burkill, I.H. 1917. Scotia erratica Smith, parasite of the red-coconut weevil (Rhynchophorus ferrugineus). Garden's Bull. 1(11\&12): 399-400

Buxton, P. A. 1920. Insect pests of dates and the date palm in Mesopotamia and elsewhere. Bull. Entomol. Res. 11: 287-303.
CABI, 2002. Crop Protection Compendium (Second Edition). CAB International, Wallingford, UK.

Chinchilla, C. M. 1988. The red ring-little leaf syndrome in oil palm and coconut. Bol. Técnico $O P O-C B \quad 24: \quad 113-136$ and Agricultural Services and Development, Technical Bull. 1, 1991, San José, Costa Rica.

Chinchilla, C. M., Menjivar, R. and Arias, E. 1990. Picudo de la palma y enfermedad del anillo rojo/hoja pequeña en una plantación comercial de palma aceiteera en Honduras. Turrialba 40: 471-477.

Chinchilla, C. M., Oehlschlager, A. C and Gonzalez, L. M. 1993. Use of pheromonebased traps for the management of the American palm weevil, Rhynchophorus palmarum in a commercial oil palm plantation, p. 19 In: Proceedings International Oil Palm Congress, 20-25 September 1993. Palm Oil Research Institute of Malaysia, Kuala Lumpur, Malaysia.

Chinchilla, C. M., Oeshlschlager, A. C. and Bulgarelli, J. 1996. A Pheromone Based Trapping System for Rhynchophorus palmarum and Metamasius hemipterus. ASD Oil Palm Papers 12: 11-17.

Chittenden, F. H. 1902. The palm and palmetto weevils. U.S. Dept. Agr. Entomol. Bull. 38: 23-28.

Chowdhury, D., Nath, J. C. and Mohan, N. K. 2001. 'Kamrupa'-a newly released coconut variety by Assam Agricultural University. Indian Cocon. J. 31(9): 12-13.

Cobb, N. A. 1922. A note on the coconut enemy of Panama. J. Parasitol. 9: 44-45.

Cox, M. L. 1993. Red palm weevil, Rhynchophorus ferrugineus in Egypt. FAO Plant Prot. Bull. 41(1): 30-31.

Danger, T. K. 1997. Infection of red palm weevil. Rhynchophorus ferrugineus by yeast. J. Plant. Crops 25(2): 193-196. 
Diegado, H. V. and Moreno, F. O. 1986. Evaluación de atrayentes vegetales y un sistema de trampa para la captura de adultos de "gualpa" (Rhynchophorus palmarum) insecto-plaga de palma Africana y cocotero. Inst. Nac. Invest. Agropecu. Bol. Tec. 63, Estación Experimental Santo Domingo, Ecuador.

Dusenbery, D. B. 1992. Sensory Ecology. W. H. Freeman and Co., New York, New York. 558pp.

El Ezaby, F. A. 1977. Injection as a method to control the Red Indian date palm weevil Rhynchophorus ferrugineus. Arab J. Plant Prot. 15(1): 31-38.

El Ezaby, F. A., Khalifa, O. and El Assal, A. 1998. Integrated pest management for the control of red palm weevil Rhynchophorus ferrugineus Oliv. in The United Arab Emirates, Eastern Region, Al Ain. In: Proceedings of the First International Conference on Date Palms, M. A. RahmanAl Afifi and A. Al-Sherif Al-Badawy (Eds.), Al-Ain, UAE, 8-10 March 1998. Faculty of Agricultural Sciences, UAE University, pp. 269-281.

El Garhy, M. E. 1996. Field evaluation of the aggregation pheromone of the red palm weevil, Rhynchophorus ferrugineus in Egypt, pp. 18-21. In: Brighton Crop Protection Conference: Pests \& Diseases: Vol. 3; Proceedings of an International Conference. 15-21 November, Brighton, UK.

El Sebay, Y. 2003. Ecological studies on the red palm weevil Rhynchophorus ferrugineus Oliv. (Coleoptera: Curculionidae) in Egypt. Egyptian J. Agric. Res. 81: 523-529.

Esteban Duran, J., Yela, J. L., Jiménez, A. and Beitia Crespo, F. 1998b. Exotic curculionids susceptible to being introduced into Spain and other countries of the European Union through imported vegetables (Coleoptera: Curculionidae: Rhyncho-phorinae). [Curculionidos exoticos susceptibles de ser introducidos en Espana y otros paises de la Union Europea a traves de vegetales importados (Coleoptera: Curculionidae: Rhynchophorinae)]. Bol. Sanidad Veg. Plag. 24(1): 23-40.

Esteban Duran, J., Yela, J. L., Jiménez, A. and Beitia Crespo, F. 1998a. Biology of red palm weevil, Rhynchophorus ferrugineus Olivier in the laboratory and field, life cycle, biological characteristics in its zone of introduction in Spain, biological method of detection and possible control [Biología del curculiónido ferruginoso de las palmeras Rhynchophorus ferrugineus (Olivier) en laboratorio y campo: ciclo en cautividad, peculiaridades biológicas en su zona de introducción en España y métodos biológicos de deteccción y posible control] (Coleoptera: Curculionidae: Rhynchophorinae). Bol. Sanidad Veg. Plag. 24(4): 737-748.

Faghih, A. A. 1996. The biology of red palm weevil, Rhynchophorus ferrugineus Oliv. (Coleoptera, Curculionidae) in Savaran region (Sistan province, Iran). Appl. Entomol. Phytopathol. 63(1\&2): 16-86.

Faleiro J. R. and Satarkar, V. R. 2002. Suitability of insecticides for use in red palm weevil pheromone traps. Pestology 26(5): 34-36.

Faleiro, J. R. 2000. Investigation on the role of pheromone trapping in the suppression of red palm weevil, Rhynchophorus ferernigineus Oliv. population in coconut plantations, Extended summaries. Int. Conf. Manag. Nat. Res. Sust. Agric. Prod. $21^{\text {th }}$ Century 3: 1338-1339.

Faleiro, J. R. and Chellapan, M. 1999. Attraction of red palm weevil, Rhynchophorus fererugineus Oliv. to ferrugineol based pheromone lures in coconut gardens. J. Trop. Agric. 37: 60-63.

Faleiro, J. R. and Rangnekar, P. A. 2001b. Location specific seasonal activity of red palm weevil, Rhynchophorus ferrugineus Oliv, in coconut plantations of Goa. Indian J. Appl. Entomol. 15(2): 7-10. 
Faleiro, J. R. and Rangnekar, P. A. 2001c. Field longevity of red palm weevil attracting pheromone (ferrolure + ) in coconut plantations. In: Proceedings Second National Symposium on IPM in Horticultural Crops: New Molecules, Biopesticides and Environment, Bangalore, India, 17-19, October 2001.

Faleiro, J. R., Abraham, V. A., Nabil, B., AlShuaibi, M. A. and Prem Kumar, T. 2000. Field evaluation of red palm weevil, Rhynchophorus ferrugineus Oliv. Pheromone (Ferrugineol) lures. Indian J. Entomol. 62(4): 427-433.

Faleiro, J. R., Al-Shuaibi, M. A., Abraham, V. A. and Prem Kumar, T. 1999. A Technique to assess the longevity of the pheromone (Ferrolure) used in trapping the date red palm weevil, Rhynchophorus ferrugineus Oliv. Agric. Sci. 4(1): 5-9

Faleiro, J. R., Ashok Kumar, J. and Rangnekar, P. A. 2002. Spatial distribution of red palm weevil Rhynchophorus ferrugineus Oliv. (Coleoptera: Curculionidae) in coconut plantations. Crop Prot. 21(2): 171-176.

Faleiro, J. R., Rangnekar, P. A. and Satarkar, V. R. 2003. Age and fecundity of female red palm weevils Rhynchophorus ferrugineus (Olivier) (Coleoptera: Rhynchophoridae) captured by pheromone traps in coconut plantations of India. Crop Prot. 22(7): 999-1002.

Faleiro. J. R. and Rangnekar, P. A. 2001a. Ovipositional preference of red palm weevil. Rhynchophorus ferrugineus Oliv. to coconut cultivars. Indian Cocon. J. 32(6): 22-23.

Falerio, J. R. and Satarkar, V. R. 2003. Ferrugineol based pheromone lures for trapping red palm weevil, Rhynchophorus ferrugineus Olivier (Coleoptera: Rhynchophoridae) in coconut plantations. Indian J. Plant. Prot. 31(1): 84-87.

Falerio, J. R., Abraham, V. A. and Al-Shuaibi, M. A. 1998. Role of pheromone trapping in the management of red palm weevil. Indian Cocon. J. 29(5): 1-3.

Fenwick, D. W. 1968. Red ring disease of the coconut palm, pp. 38-48. In: Tropical Nematology, Center for Tropical Agriculture, G. C. Smart, Jr. and V.G.V. Preey (Eds.). University Agriculture Press, Gainesville, FL., USA.

Gerber, K. and Giblin-Davis, R. M. 1990. Teratorhabditis sp. (Nematoda, Rhabditidae) - an associate of Rhynchophorus palmarum and $R$. cruentatus. J. Nematol. 22(3): 337-347.

Gerber, K., Giblin-Davis, R. M. and EscobarGoyes, J. 1990. Association of the red ring nematode, Rhadinaphelenchus cocophilus, with weevils from Ecuador and Trinidad. Nematropica 20: 39-49.

Ghazavi, M. and Faghih, A. A. 2002. Isolation of two entomopathogenic fungi on red palm weevil, Rhynchophorus ferrugineus (Olivier) (Col., Curculionidae) in Iran. App. Entomol. Phytopath. 69(2): 44-45, 191.

Giblin-Davis, R. M. 1993. Interactions of nematodes with insects, pp. 302-344. In: Nematode Interactions, W. Khan (Ed.). Chapman \& Hall, London, 377 pp.

Giblin-Davis, R. M. and Howard, F. W. 1989b. Vulnerability of stressed palms to attack by Rhynchophorus cruentatus (Fabricius) (Coleoptera: Curculionidae) and insecticidal control of the pest. J. Econ. Entomol. 82: 1185-1190.

Giblin-Davis, R. M., Gerber, K. and Griffith, R. 1989a. Laboratory rearing of Rhynchophorus cruentatus and $R$. palmarum (Coleoptera: Curculionidae). Florida Entomol. 72: 480-488.

Giblin-Davis, R. M., Gries, G., Gries, R., PenaRojas, E., Pinzon, I., Peña, J. E., Oehschlager, A. C., Perez, A. L. and Pierce, H. D. Jr. 1997. Aggregation pheromone of palm weevil, Dynamis borassi. J. Chem. Ecol. 23(10): 2287-2297. 
Giblin-Davis, R. M., Oehschlager, A. C., Perez, A., Gries, G., Gries, R., Weissling, T. J., Chinchilla, C. M., Peña, J. E., Hallett, R. H., and Pierce, Jr. H. D. 1996a. Chemical and behavioral ecology of palm weevils. Florida Entomol. 79(2): 154-167.

Giblin-Davis, R. M., Peña, J. E. and Duncan, R. E. 1994a. Lethal pitfall trap for evaluation of semiochemical-mediated attraction of Metamasius hemipterus sericeus (Coleoptera: Curculionidae). Florida Entomol. 77: 247-255.

Giblin-Davis, R. M., Peña, J. E. and Duncan, R. E. 1996b. Evaluation of an entomopathogenic nematode and chemical insecticides for control of Metamasius hemipterus sericeus (Coleoptera: Curculionidae). J. Entomol. Sci. 31: 240-251.

Giblin-Davis, R. M., Weissling, T. J., Oehlschlager, A. C. and Gonzalez, L. M. 1994b. Field response of Rhynchophorus cruentatus (Coleoptera: Curculionidae) to its aggregation pheromone and fermenting plant volatiles. Florida Entomol. 77: 164-177.

Gopinadhan, P. B., Mohandas, N. and Nair, K. P. V. 1990. Cytoplasmic polyhedrosis virus infecting red palm weevil of coconut. Curr. Sci. 59(11): 577-580.

Green, E. E. 1906. Rhynchophorus ferrugineus. Trop. Agri. 27.

Gries, G., Gries, R., Perez, A. L., Gonzales, L. M., Pierce, H. D. Jr., Oehlschlager, A. C., Rhainds, M., Zebeyou, M. and Kouame, B. 1994. Ethyl propionate: synergistic kairomone for African palm weevil, Rhynchophorus phoenicis L. (Coleoptera: Curculionidae). J. Chem. Ecol. 20: 889-897.

Gries, G., Gries, R., Perez, A. L., Oehlschlager, A. C., Gonzales, L. M., Pierce, Jr. H. D., Kouda-Bonafos, M., Zebeyou, M. and Nanou, N. 1993. Aggregation pheromone of African palm weevil, Rhynchophorus phoenicis F. Naturwessenschafien 80: 90-91.
Griffith, R. 1967. Progress on the entomological aspects of red ring disease of coconuts. $J$. Agric. Soc. Trin. Tob. 67: 209-218.

Griffith, R. 1978. Epidemiology of red ring disease of coconuts in Trinidad and Tobago. J. Agric. Soc. Trin. Tob. 78: 200-217.

Griffith, R. 1987. Red ring disease of coconut palm. Plant Dis. 71: 193-196.

Guimares, J. H., Townsend, C. H. T. and van Emden, F. 1977. A revision of the genus Paratheresia Townsend (Diptera: Tachinidae, Theresiini). Papers Avulsos Zool. 30: 267-288.

Gunatilake, R. and Gunawardena, N. E. 1986. Ethyl alcohol: a major attractant of red weevil Rhynchophorus ferrugineus, p. 70. In: Proc. Sri Lanka Assoc. Adv. Sci., 42 ${ }^{\text {nd }}$ Annual Session.

Gunawardena, N. E. and Bandaruge, U. K. 1995. 4-Methyl-5-nonanol (ferrugineol) as an aggregation pheromone of the coconut pest, Rhynchophorus ferrugineus F. (Coleoptera: Curculionidae): synthesis and use in a preliminary field assay. J. Nat. Sci. Council Sri Lanka, 23(2): 71-79.

Gunawardena, N. E. and Herath, H. M. 1995. Enhancement of the activity of ferrugineol by $\mathrm{N}$-pentanol in an attractant baited trap for the coconut pest, Rhynchophorus ferrugineus F. (Coleoptera: Curculionidae). J. Nat. Sci. Council, Sri Lanka 23(2): 81-86.

Gunawardena, N. E., Kern, F., Janssen, E., Meegoda, C., Schafer, D., Vostrowsky, O. and Bestmann, H. J. 1998. Host attractants for red weevil, Rhynchophorus ferrugineus: Identification, electrophysiological activity, and laboratory bioassay. J. Chem. Ecol. 24(3): 425-437.

Gush, H. 1997. Date with disaster, The Gulf Today, September 29, p. 16.

Hagley, E. A. C. 1963. The role of the palm weevil, Rhynchophorus palmarum, as a vector of red ring disease of coconuts. I. Results of preliminary investigations. $J$. Econ. Entomol. 56: 375-380. 
Hagley, E. A. C. 1965. Tests of attractants for the palm weevil. J. Econ. Entomol. 58: 1002-1003.

Halfpapp, K. H., and Storey, H. I. 1991. Cane weevil borer, Rhabdoscelus obscurus (Coleoptera: Curculionidae), a pest of palms in Northern Queensland, Australia. Principes 35: 199-207.

Hallett, R. H., Gries, G., Gries, R., Borden, J. H., Czyzewska, E., Oehlschlager, A. C., Pierce Jr., H. D., Angerilli, N. P. D. and Rauf, A. 1993a. Aggregation pheromones of two Asian palm weevils, Rhynchophorus ferrugineus and $R$. vulneratus. Naturwissenschafien 80: 328- 331.

Hallett, R. H., Oehlschlager, A. C. and Borden, J. H. 1999. Pheromone trapping protocols for the Asian palm weevil, Rhynchophorus ferrugineus (Coleoptera: Curculionidae). Int. J. Pest Mgt. 45(3): 231-237.

Hallett, R. H., Oehlschlager, A. C., Gries, G., Angerilli, N. P. D., Shareqi, R. K., Gasouma, M. S. and Borden, J. H. 1993b. Field testing of aggregation pheromones of two Asian palm weevils, pp. 661-668. In: PORIM International Oil Palm Congress, Kuala Lumpur, Malaysia.

Hamburger, M., Bitton, S. and Nakache, J. 2003. Control of red palm weevil (Rhynchophorus ferrugineus) (Coleoptera: Curculionidae), a quarantine pest in Israel. Abstract of a paper presented at the 20th Conference of the Entomological Society of Israel (Bet Dagan, IL, 2003-02-11/12). Phytoparasitica 31(3): 299-300.

Hanounik, S. B. 1998. Steinernematids and heterorhabditids as biological control agents for the red palm weevil (Rhynchophorus ferrugineus Oliv.). Sultan Qabus Univ. J. Scientif. Res. Agric. Sci. 3: 95-102.

Hanounik, S. B., Saleh, M. M. E., Abuzuhairah, R. A., Alheji, M., Aldhahir, H. and Aljarash, Z. 2000. Efficacy of entomopathogenic nematodes with antidesiccants in controlling the red palm weevil, Rhynchophorus ferrugineus on date palm trees. Int. J. Nematol. 10(2): 131-134.

Hernandez-Marante, D., Folk, F., Sanchez, A. and Fernandez-Escobar, R. 2003.Control of red palm weevil (Rhynchophorus ferrugineus Olivier) using trunk injections and foliar sprays (Control del curculionido ferruginoso de las palmeras (Rhynchophorus ferrugineus Olivier) mediante inyecciones al tronco y pulverizacion foliar). Boletin de Sanidad Vegetal, Plagas 29(4): 563-573.

Hill, D.S. 1983. Agricultural insect pests of the tropics and their control. 2nd edition.Cambridge University Press, Cambridge, 746 pp.

Iyer, C.S.V. 1940. Two interesting and unrecorded enemies of the palm beetle, Rhynchophorus ferrugineus. Indian $J$. Entomol. 2: 98.

Jaffé, K., Sanchez, P., Cerda, H., Hernandez, J. V., Jaffé, R., Urdaneta, N., Guerra, G., Martinez, R. and Miras, B. 1993. Chemical ecology of the palm weevil Rhynchophorus palmarum (L.) (Coleoptera: Curculionidae): attraction to host plants and to a maleproduced aggregation pheromone. J. Chem. Ecol. 19: 1703-1720.

Kalshoven, L. G. E. 1981. Pests of crops in Indonesia. P. T. Ichtiar Baru-Vanhoeve, Jakarta, 701 pp.

Kehat, M. 1999. Threat to date palms in Israel, Jordan and the Palestinian authority by the red palm weevil, Rhynchophorus ferrugineus. Phytoparasitica 27: 107-108.

Krishnakumar, R. and Sudha, G. 2002. Indian tree pie Dendrocitta vagabunda parvula (Whistler and Kinnear) (Corvidae) - a predatory bird of red palm weevil Rhynchophorus ferrugineus (Oliv.). Insect Environ. 8(3): 133.

Kurian, C., Abraham, V. A. and Ponnamma, K. N. 1984. Attractants - an aid in red palm weevil management, pp. 581-585. In: Proceedings PLACROSYM V, Dec. 15-18, 1982, Kasaragod, India. 
Kurian, C., Sathiamma, B., Sukumaran, A. S. and Ponnamma, K. N. 1979. Role of attractants and repellents in coconut pest control in India. Paper presented at the 5 session of the FAO technical working party, Manila.

Lefroy, H. M. 1906. The more important insects injurious to Indian Agriculture. Govt. Press, Culcutta.

Lever, R. J. A. W. 1969. Pests of coconut palm (Curculionidae) FAO, Rome, pp. 113-119.

Maharaj, S. 1973. A new design of traps for collecting the palm weevil, Rhynchophorus palmarum. Ceylon Cocon. Planters Rev. 7: 5-7.

Mariau, D. 2002. The insects pests of coconut, pp. 104-116. In: Modern Coconut Management - Palm Cultivation and Products, J. G. Ohler (Ed.). Food and Agriculture Organization, 416 pp.

Martyn, E. B. 1953. Red ring disease of coconuts in Trinidad and Tobago. Trop. Agric, Trinidad 30: 43-53.

Mathen, K. and Kurian, C. 1967. Insecticidal trials against Rhynchophorus ferrugineus $\mathrm{F}$. the coconut weevil. Indian J. Agric. Sci. 37(4): 23 1- 235.

Mayilvaganan, M., Nair, C. P. R., Shanavas, M. and Nair, S. S. 2003. Field assay of locally synthesized ferrugineol for trapping Rhynchophorus ferrugineus. Indian Cocon. J. 29: 8-9.

Mazumder, N. 1995. Reaction of coconut cultivar and hybrids to the incidence of different pests and diseases. Hort. J. Assam Agric. Univ., Jorhat 8(2): 147- 149.

Mercer, C. W. L. and Bukkens, S. G. F. 1997. Sustainable production of insects for food and income by New Guinea villagers. Minilivestock Ecol. Food Nutr. 36(2-4): 151157.

Monzer, A. E. and El-Rahman, R. A. 2003. Effect on Heterorhabditis indica of substances occurring in decomposing palm tissues infested by Rhynchophorus ferrugineus. Nematology 5(5): 647-652.

Morales, J. L. and Chinchilla, C. M. 1990. Estudios poblacionales en Rhynchophorus palmarum y su relación con la enfemedad del anillo rojo/hoja pequeña en palma aceitera en Costa Rica. Turrialba 40(4): 478-485.

Morin, J. P., Luchini, F., Araujo, J. C. A., Ferreira, J. M. S. and Fraga, L. S. 1986. Rhynchophorus palmarum control using traps made from oil palm cubes. Oleagineux 41: 57-62.

Moura, J.I.L., Fanton, C.J. and Mesquita, C.A.B. 2002. Evaluacion de un metodo agronomico, biologico y quimico para el combate de Amerrhinus ynca en plantaciones de coco. Manejo Integrado de Plagas y Agroecologia 65: 109-112.

Moura, J.I.L., Mariau, D. and Delabie, J.H.C. 1993. Efficacy of Paratheresia menezesi Townsend (Diptera: Tachinidae) for natural biological control of Rhynchophorus palmarum (L.) (Coleoptera: Curculionidae). Oléagineux 48: 219-223.

Moura, J.I.L., Mariau, D. and Delabie, J.H.C. 1994. Control strategy against Amerrhinus ynca Sahlb. 1823 (Coleoptera: Curculionidae), coconut (Cocos nucifera L.) leaf rachis borer in Brazil. Oléagineux 49: 222-226.

Moura, J.I.L., Resende, M.L.B. de and Vilela, E.F. 1995. Integrated pest management of Rhynchophorus palmarum (L.) (Coleoptera: Curculionidae) in oil palm in Bahia. Anais da Sociedade Entomológica do Brasil 24: 501-506.

Murphy, S. T. and Briscoe, B. R. 1999. The red palm weevil as an alien invasive: biology and the prospects for biological control as a component of IPM. BNI 20(1): 35-46.

Muthuraman, M. 1984. Trunk injection of undiluted insecticides - a method to control coconut red palm weevil, Rhynchophorus ferrugineus Fab. Indian Cocon. J. 15(2): 12-14. 
Nair, C. P. R., Nair, S. S. and Abraham, V. A. 2002. An IPM module for red palm weevil. Extended Summaries. National Conference on Coastal Agricultural Research, Goa, India, 6-7 April, 2002.

Nair, S. S., Abraham, V. A. and Nair, C. P. R. 2000. Efficiency of different food baits in combination with pheromone lures in trapping adults of red weevil, Rhynchophorus ferrugineus Oliv. (Coleoptera: Curculionidae). Pestology 24(6): 3-5.

Napompeth, B., Nishida, T. and Mitchell, W. C. 1972. Biology and rearing methods of the New Guinea sugarcane weevil, Rhabdoscelus obscurus. Hawaii Agricultural Experiment Station College of Tropical Agriculture. Univ. Hawaii Tech. Bull. 85.

Nirula, K.K. 1956.Investigations on the pests of the coconut palm. Part IV: Rhynchophorus ferrugineus Oliv. Indian Cocon. J. 10(1): 28-44.

Oehlschlager, A. C. Chinchilla, C. M. and Gonzalez, L. M. 1993a. Optimization of a pheromone-based trap for the American palm weevil, Rhynchophorus palmarum. In: Proceedings, International Oil Palm Congress, 20-25 September 1993. Palm Oil Research Institute of Malaysia, Kuala Lumpur, Malaysia.

Oehlschlager, A. C., Chinchilla, C. M. and González, M. 1992b. Management of the American palm weevil (Rhychophorus palmarum) and the red ring disease in oil palm by pheromone-based trapping. ASD Oil Palm Papers 5: 15-23.

Oehlschlager, A. C., Chinchilla, C. M., Gonzalez, L. M., Jiron, L. F., Mexzon, R. G. and Morgan, B. 1993b. Development of a pheromone-based trapping system for the American Palm Weevil, Rhynchophorus palmarum. J. Econ. Entomol. 86(5): 1381-1392.

Oehlschlager, A. C., McDonald, R. S., Chinchilla, C. M. and Patschke, S. N. 1995b. Influence of a pheromone-based mass-trapping system on the distribution of Rhynchophorus palmarum
(Coleoptera: Curculionidae) in oil palm. Environ. Entomol. 24(5): 1005-1012.

Oehlschlager, A. C., Pierce, H. D., Morgan, B., Wimalaratne, P. D. C., Slessor, K. N., King, G. G., Gries, G., Gries, R., Rorden, J. H., Jiron, L. F., Chinchilla, C. M. and Mexzon, R. G. 1992a. Chirality and field activity of Rhynchophorol, the aggregation pheromone of the American palm weevil. Naturwessenschaften 79(3): 134-135.

Oehlschlager, A. C., Prior, R. N. B., Perez, A. L., Gries, R., Gries, G., Pierce, H. D. Jr., and Laup, S. 1995a. Structure, chirality and fieldtesting of a male-produced aggregation pheromone of Asian palm weevil Rhynchophorus bilineatus (Montr.) (Coleoptera: Curculionidae). J. Chem. Ecol. 21(10): 1619-1629.

Oehschlager, A. C., Chinchilla, C., Castilo, G. and Gonzalez, L. 2002. Control of red ring disease by mass trapping of Rhynchophorus palmarum (Coleoptera: Curculionidae). Florida Entomol. 85(3): 507-513.

Peña, J. E., Giblin-Davis, R. M. and Duncan, R. E. 1995. Impact of indigenous Beauveria bassiana (Balsamo) Vuillemin on banana weevil and rotten sugarcane weevil (Coleoptera: Curculionidae) populations in banana in Florida. J. Agric. Entomol. 12: 163-167.

Perez, A. L., Gries, G., Gries, R., Giblin-Davis, R. M., and Oehlschlager, A. C. 1994. Pheromone chirality of African palm weevil, Rhynchophorus phoenicis (F.) and palmetto weevil, Rhynchophorus cruentatus (F.) (Coleoptera: Curculionidae). J. Chem. Ecol. 20: 2653-2671.

Perez, A. L., Hallett, R., Gries, R., Gries, G., Pierce, H. D. Jr., Borden, J. H. and Oehlschlager, A. C. 1995. Pheromone chirality of the Asian palm weevils, Rhynchophorus ferrugineus (Oliv.) and Rhynchophorus vulneratus (Panz.), (Coleoptera: Curculionidae). J. Chem. Ecol. 22(2): 357-368. 
Peter, C. 1989. A note on the mites associated with the red palms weevil, Rhynchophorus ferrugineus Oliv. in Tamil Nadu. J. Insect Sci. 2(2): 160-161.

Poinar, G. O. Jr. 1969. Praecocilenchus rhaphidophorus n. gen., n. sp. (Nematoda: Aphelenchoidea) parasitizing Rhynchophorus bilineatus (Montrouzier) (Coleoptera: Curculioni-dae) in New Britain. J. Nematol. 1: 227-231.

Prior, C. and Arura, M. 1985. The infectivity of Metarhizium anisopliae to two insect pests of coconuts. J. Invert. Pathol. 45: 187-I 94.

Quezada, J. R., Amaya, C. A. and Herman, L. H. Jr. 1969. Xanthopygus cognatus Sharp (Coleoptera: Staphylinidae) an enemy of the coconut weevil, Rhynchophorus ferrugineus L. (Coleoptera: Curculionidae) in Elsavador. file://D: $\backslash \mathrm{PW}-\mathrm{El}$ picudo de las palmas.htm.

Rahalkar, G. W., Harwalkar, M. R., Rananavare, H. D., Shantaram, K. and Gopalyengar, A. R. 1973. Laboratory studies on radiation sterilization of red palm weevil, Rhynchophorus ferrugineus. Oliv. males. J. Plant. Crops, (Suppl. I): 141-145.

Rajamanickam, K., Kennedy, J. S. and Christopher, A. 1995. Certain components of integrated management for red palm weevil, Rhynchophorus ferrugineus F. (Curculionidae: Coleoptera) on coconut. Mededelingen Faculteit Landbouwlatndige en Toegepaste Biologische Wetenschappen 60: 803-805.

Ramachandran, C. P. 1998. Biotypic variability among four populations of red palm weevil, Rhynchophorus ferrugineus Oliv. from different parts of India. Cord 14(1): 26-41.

Rao, G. A., Rao, R. P., Rao, R. T. and Laxminarayana, K. 1989. Studies on the effect of root feeding of systemic insecticides in the control of red palm weevil, Rhynchophorus ferrugineus Fab. in coconut. Indian Cocon. J. 19(9): 12-16.

Rao, P. N. and Reddy, Y. N. 1980. Description of a new nematode Paraecocilenchus rhaphidophorus sp. nov from weevil pests (Coleoptera) of coconut palms in South India. Rivista di Parassitologia 44(1): 93-98.

Rao, P. V. S., Subramaniam, T. R. and Abraham, E. V. 1973. Control of the red palm weevil on coconut. J. Plant. Crops 1(1\&2): 26-27.

Rochat, D., Akamou, F., Sangare, A., Mariau, D. and Mori, K. 1995. Field trapping of Rhynchophorus phoenicis with stereoisomers of the synthetic aggregation pheromone. Curr. Res. Acad. Sci. Paris Ser. III 318: 183-190.

Rochat, D., Descoins, C., Malosse, C., Nagnon, P., Zagatti, P., Akamou, F. and Mariau, D. 1993a. Ecologie chimique des charamons des palmiers, Rhynchophorus spp. (Coleoptera). Oléagineux 48: 225-236.

Rochat, D., Gonzalez, A., Mariau, D., Villanueva, A. G. and Zagatti, P. 1991a. Evidence for male-produced aggregation pheromone in American palm weevil, Rhynchophorus palmarum (L.) (Coleoptera: Curculionidae). J. Chem. Ecol. 17: 1221-1230.

Rochat, D., le Meillour, P. N., Esteban Duran, J. R., Malosse, C., Perthuis, B., Morin, J. P. and Descoins, C. 2000. Identification of pheromone synergists in American palm weevil, Rhynchophorus palmarum, and attraction of related Dynamis borassi. J. Chem. Ecol. 26: 155-187.

Rochat, D., Mallose, C., Lettere, M., Ducrot, P. H., Zagatti, P., Renou, M. and Descoins, C. 1991b. Male-produced aggregation pheromone of the American palm weevil, Rhynchophorus palmarum (L.) (Coleoptera: Curculionidae): collection, identification, electro-physiological activity, and laboratory bioassay. J. Chem. Ecol. 17: 2127-2141.

Rochat, D., Malosse, C., Lettere, M., RamirezLucas, P. and Zagatti, P. 1993c. Identification of new pheromone-related compounds from volatiles produced by males of four Rhynchophorinae weevils (Coleoptera, 
Curculionidae). Curr. Res. Acad. Sci. Paris Ser. II 316: 1737-1742.

Salama, H. S., Foda, M.S., El-Bendary, M.A. and Abdel-Razek, 2004. A Infection of red palm weevil, Rhynchophorus ferrugineus, by spore-forming bacilli indigenous to its natural habitat in Egypt. J.Pest Sci. 77(1): 27-31.

Schuiling, M. and Dinther, J. M. B. 1981. Red ring disease in the Paricatuba oil palm estate, Para, Brazil. Z. Angew. Entomol. 91: 154-169.

Sekhar, S. I. 2000. Titanic loss from a tiny weevil in coconut. Indian Cocon. J. 30: 8-10.

Shamseldean, M. M. and Abd-Elgawad, M. M. 1994. Laboratory evaluation of six Egyptian isolates of heterorhabditid nematodes for control of the red palm weevil. Egyptian J. Appl. Sci. 9(3): 670-679.

Simon, S., Kumar, R. K. and Gokulapalan, C. 2003. Occurrence of Beauveria sp. on red palm weevil, Rhynchophorus ferrugineus (Oliv.) of coconut. Insect Environ. 9(2): 66-67.

Soenardi Sastrosupadi, A. and Hariadi, B. 1978. The controlling of stem and top borers of coconut palms. Pemberitaan, Lembaga Penelitian Tanaman Industri, pp. 45-58.

Sosamma, V. K. and Rasmi, B.2002.Survey of entomophilic nematodes in Kerala. Indian J. Nematol. 32(2):184-185.

Thomas, J. W., Robin, M. G. and Rudolf, H. S. 1993. Laboratory and field evidence for male-produced aggregation pheromone in Rhynchophorus cruentatus (F.) (Coleoptera: Curculionidae). J. Chem. Ecol. 19: 1195-1204.

Tidman, D. A. 1951. Agricultural and horticultural problems of Brazil. World Crops 3: 341-344.

Vaurie, P. 1966. A revision of the Neotropical genus Metamasius (Coleoptera, Curculionidae, Rhynchophorinae). Species groups I and II. Bull. American Mus. Nat. Hist. 131: 213-337.
Vidyasagar, P. S. P. V., Mohammed, H., Abozuhairah, R. A., Omar A. E. and Saihati A. A. 2000. Impact of mass pheromone trapping on red palm weevil: Adult population and Infestation level in date palm gardens of Saudi Arabia. The Planter 76 (891): 347-355.

Wattanapongsiri, A. 1966. A revision of the genera Rhynchophorus and Dynamics (Colcoptera: Curculionidac). Bangkok, Thailand, Dept. Agric. Sci. Bull. No 1, 328 pp.

Weissling, T. J. and Giblin-Davis, R. M. 1993a. Water loss dynamics and humidity preference of Rhynchophorus cruentatus (Coleoptera: Curculionidae) adults. Environ. Entomol. 22: 93-98.

Weissling, T. J. and Giblin-Davis, R. M. 1994a. Fecundity and fertility of Rhynchophorus cruentatus (Coleoptera: Curculionidae). Florida Entomol. 77: 373-376.

Weissling, T. J. and Giblin-Davis, R. M. 1997. Palmetto weevil, Rhynchophorus cruentatus Fabricius (Insecta: Coleoptera: Curculionidae). Division of Plant Industry, University of Florida, Publication Number: EENY-13.

Weissling, T. J., Giblin-Davis, R. M. and Scheffrahn, R. H. 1993b. Laboratory and field evidence for a male-produced aggregation pheromone in Rhynchophorus cruentatus (Fabricius) (Coleoptera: Curculionidae). J. Chem. Ecol. 19: 1195-1203.

Weissling, T. J., Giblin-Davis, R. M., Center, B. J. and Hiyakawa, T. 1994b. Flight behavior and seasonal trapping of Rhynchophorus cruentatus (Coleoptera: Curculionidae). Ann. Entomol. Soc. America 87: 641-647.

Weissling, T. J., Giblin-Davis, R. M., Gries, G., Gries, R., Perez, A. L., Pierce, H. D. Jr., and Oehlschlager, A. C. 1994c. Aggregation pheromone of palmetto weevil, Rhynchophorus cruentatus (F.) (Coleoptera: Curculionidae). J. Chem. Ecol. 20: 505-515. 
Weissling, T. J., Giblin-Davis, R. M., Scheffrahn, R. H. and Marban-Mendoza, N. M. 1992. Trap for capturing and retaining Rhynchophorus cruentatus (Coleoptera: Curculionidae) adults using Sabal palmetto as bait. Florida Entomol. 75: 212-221.
Yoshitake, H., Masaoka, K., Sato, S., Nakajima, A. Kamitani,S. Yukawa, J. and Kojima, H. 2001. Occurrence of Rhynchophorus ferrugineus (Coleoptera: Dryophthoridae) on Nokonoshima Island, southern Japan and its possible invasion further north. Kyushu Plant Prot. Res. 47: 145-150. 